Regards sur l'économie allemande

Bulletin économique du CIRAC

118-119| 2015

Varia

\title{
Dépense publique : palmarès du " gaspi »
}

\section{Isabelle Bourgeois}

\section{OpenEdition}

\section{Journals}

Édition électronique

URL : http://journals.openedition.org/rea/4907

DOI : $10.4000 /$ rea. 4907

ISSN : 1965-0787

\section{Éditeur}

CIRAC

\section{Édition imprimée}

Date de publication : 31 décembre 2015

Pagination : 43

ISSN : 1156-8992

\section{Référence électronique}

Isabelle Bourgeois, «Dépense publique: palmarès du « gaspi » », Regards sur l'économie allemande [En ligne], 118-119 | décembre 2015, mis en ligne le 31 décembre 2017, consulté le 15 septembre 2020 URL : http://journals.openedition.org/rea/4907

Ce document a été généré automatiquement le 15 septembre 2020.

(c) CIRAC 


\title{
Dépense publique : palmarès du " gaspi »
}

\author{
Isabelle Bourgeois
}

1 La rigueur budgétaire, si elle est strictement poursuivie globalement par Bund, Länder et communes, n'en présente pas moins des lacunes de taille, épinglées tous les ans par la fédération des contribuables allemands (Bund der Steuerzahler) dans son « Livre noir » (www.schwarzbuch.de). Des bouches d'égout lumineuses dans un rond-point communal pour $10000 €$ les cinq, une application-cimetière pour les mobiles facturée la modique somme de $548000 €$, une piste cyclable de trois ans seulement transférée du trottoir sur la chaussée pour un coût de $444000 €$. Un "team efficience" constitué par le gouvernement de Rhénanie du Nord-Westphalie avec pour mission d'identifier les économies réalisables dans le budget du Land et qui la facture 1,8 million $€$ sans présenter la moindre piste. Une campagne publicitaire pour la Bundeswehr à 10,6 millions €... "L'Allemagne n'a pas un problème de recettes [fiscales], mais un problème de dépenses inconsidérées ! » tempête la Fédération.

2 Celle-ci ne se contente pas de repérer le « gaspi », sa critique est constructive, car elle formule aussi toute une série de recommandations à destination des pouvoirs publics. Dernièrement, elle a ainsi contribué à la simplification des formulaires de déclaration des revenus 2015 ou à la débureaucratisation comme la facilitation des déclarations d'impôt via Internet. Elle joue ainsi pleinement son rôle de représentation légitime des intérêts des contribuables dans la société allemande.

\section{INDEX}

Mots-clés : dépenses 